\title{
Can "Withitness Skills" Be Applied To Teaching With Laptops?
}

\author{
Larry McDaniel, Dakota State University, USA \\ Allen Jackson, Chadron State College, USA \\ Laura Gaudet, Chadron State College, USA \\ Andrew Shim, Dakota State College, USA
}

\begin{abstract}
It may amaze those in education that in this age of technology and computers, how basic concepts of classroom teaching are similar or even more important than they were 40 years ago when Kounin first defined withitness elements. New challenges, related to laptop Internet instruction, require instructors to develop "withitness" skills and situational awareness as they compete with computers for students' attention and class participation. "Withitness" skills may be needed when teaching students in classrooms with laptops connected to the Internet.
\end{abstract}

\section{INTRODUCTION}

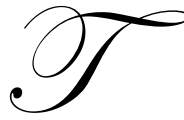

he purpose of this paper is to discuss how "withitness" may be used in teaching students in classrooms with laptops connected to the Internet. New challenges, related to laptop Internet instruction, require instructors to develop "withitness" skills and situational awareness as they compete with computers for students' attention and participation. The following are examples of new problems that laptops and the Internet have created in the classroom:

- $\quad$ Not focusing on the lesson:

$\circ \quad$ Sending and receiving e-mail messages

- Internet surfing

- Playing games (hearts, solitaire, etc.)

- Watching Internet TV (sports, soap operas, etc.)

- Popup pictures related to received emails

- Students trying to pay attention to the instructor; students who can see what other students have opened on their computer

- Internet testing:

$\circ \quad$ Loading clipboards with test-related information used for cheating purposes during testing

- Sending E-mails or receiving test answers from other students while a test is in progress

$\circ$ Observing other students' laptop screens in search for answers

Since the 1970's, "withitness" has been emphasized as an important tool for classroom management (Kounin, 1970). "Withit" instructors develop the ability to know what is going on in the classroom and minimize misbehavior through observation skills. Jacob Kounin was a classroom management theorist. Prior to Kounin, most people felt discipline and instruction were separate entities. Many thought that teaching was helping students acquire knowledge and learn new skills. Discipline is how a teacher keeps students engaged in learning while maintaining proper behavior. Kounin worked to change this view and integrate teaching and discipline. Originally, he studied teaching strategies specific to disciplinary problems in the classroom. He soon realized teaching was more than the clarification of expectations involving classroom etiquette. He soon realized that what the teacher did in reaction to student behavior was very important. To better define these classroom expectations, the teacher needed to establish rules of behavior and consequences prior to the start of the lesson and review them as needed throughout the length of the class. 
All of this came about from an incident that occurred while Kounin was teaching a class in Mental Hygiene. A student in the back of the classroom was reading a newspaper with the paper fully open to block any contact with the instructor. Kounin asked the student to put the paper away and pay attention. Once the student complied, Kounin realized that a number of students who were engaged in unfavorable behaviors stopped and began to pay attention to the lecture. This created an interest for Kounin in understanding classroom discipline and behavior and how it relates to student learning. Through Kounin's observations, he identified what is now known as the Ripple Effect. According to the Kounin Model, when an instructor interrupts the class due to the misbehavior of one student, it often influences the behavior of other students as well (Wuest, 1999).

Kounin wrote a book "Discipline and Group Management in Classrooms" to summarize the behaviors of effective and ineffective classroom managers. He discussed what teachers did to stop misbehavior, but found that no matter how the teacher handled the situation, it did not change the student's reaction. He concluded the way teachers handled misbehavior when it occurs was not the key to successful classroom management. The answer to successful classroom management was in the instructor's actions prior to the problem behavior. One example involved a teacher who would flick the lights off and on prior to beginning a lesson. This worked well for her, but in another classroom setting, flicking the lights had no effect.

Kounin carried on his classroom management studies for five years. During that time, he experimented with college, high school, and elementary students. He compiled data based on videotape segments taken from diverse learning communities. He found that organization and planning of curriculum were instrumental to good classroom management, along with a proactive approach to management on the part of the teacher. Through these actions, higher levels of student involvement were realized. Teachers need to have good lesson movement which contributes to the unification of effective management and effective teaching. These principles can be maintained through observation, overlapping, momentum, smoothness, and group focus.

For those who supplement classroom instruction with technology via the use of laptop computers, rules regarding Internet use in the classroom must be developed with consequences that are well defined and enforced. The instructor must engage the students with a wide selection of lessons. By using computer laptops as a tool for learning, such as note taking and filing information, a number of different learning experiences are offered; therefore a larger number of learning modalities can be addressed.

\section{WITHITNESS}

"Withitness," was a term developed by Kounin (Wuest 1999) to illustrate a teacher's awareness of what was going on simultaneously in the classroom. To the unsuspecting learner, it would seem as though instructors are blessed with a skill indicative of a rare physiological state where they have eyes located at the back of their head. This phenomenon is often recognized when the teacher is in a small group setting, while presenting a topic to the group, or when students are working independently. What the learner does not know is that this acquired skill is manifested through observation. It is not necessary to understand the skills of the teacher; it can all be translated in terms of student perception and what the students think of the instructor's skill.

With laptops and lessons that make use of available technology, the instructor may find that teaching in the back of the room is more effective than in the front. The instructor in the back of the room can observe what students have opened on their computers. It is important for instructors to work on the perimeter of the room exposing their back to as few students as possible or for the shortest period of time. Enforcement of rules, including Internet and laptop use, should be consistent. Instructors must be highly organized to maintain students' interest.

\section{OVERLAPPING}

Kounin described overlapping as attending to two or more events at the same time. The ability to attend to multiple things at the same time may include giving a lecture to open a new topic, while patrolling the room to prevent student misbehavior. This is closely related to withitness and Kounin felt one without the other would reduce effectiveness. The concept of instructors' multi-tasking is extremely important while competing with the Internet when the students are required to use laptops. This type of instructional practice involves teaching while 
observing computer screens. It sometimes necessitates the instructor to request that students lower their laptop screens so the instructor can make eye contact with the learners.

\section{MOMENTUM}

Momentum involves the flow of the lesson. Not only does the teacher need to know what is going to happen next, but he must be prepared for unexpected changes, such as the loss of Internet connection or while reprimanding a student who is not involved in the lesson. Maintaining high levels of student interest and engagement may be challenged by a number of occurrences such as;

When students experience satiation or boredom, other behaviors emerge. Students may introduce variations into the task, work mechanically on the task without giving it much thought, or try to create some excitement through fooling around with a classmate or engaging in other forms of misbehavior. Kounin suggests reducing satiation by providing students with a feeling of progress, offering students challenges throughout the lesson, and being enthusiastic. Variety reduces satiation and alleviates boredom. Changing the level of challenges, restructuring groups, extending the task, and using different teaching styles add variety to the lesson (Kounin, 1970).

\section{SMOOTHNESS}

Maintaining direction in the lesson and not losing focus or being diverted by irrelevant information can be accomplished by letting students know what is going to happen in class on a particular day and sticking to it. Classroom consistency involves the transitioning from one learning activity to another without a lot of disruption. Instructors should avoid the "jerkiness" of going from one task to another without direction; this may include "flip flops" where the instructor closes one subject, begins another and then jumps back to the previous subject. Kounin suggests that instructors avoids "dangles," interruptions, or inadvertently leaving something unfinished and returning later. He also suggested teachers minimize truncation. This is experienced when the teacher is interrupted, leaves the topic and fails to return to it (Kounin). Instructors need to have transitions ready for Internet use. The use of computers for classroom instruction can be immensely valuable while offering lessons that require multimedia components, such as word documents, URLs, or more than one Internet site to be used during the learning experience.

\section{GROUP FOCUS}

The focus of any educational experience involves student engagement. To one who has not experimented with technology in the classroom, it can be a daunting task to keep the entire class significantly involved. Lessons need to be well thought out, while the presentation needs to be stimulating to evoke high levels of interest. Students are enticed into the learning experience through careful planning and a basic concept of instructional design. With these carefully thought out principles, students are less likely to try and find other avenues of interest. Instructors must make them accountable for their behavior without disruptions to the entire class. Preparation and planning Internet usage is a critical element for student focus.

\section{BEHAVIOR TECHNIQUES}

Withitness involves the teacher's ability to know what students are doing in the classroom at all times. It also includes stopping behavior problems before they begin. The teacher should:

- $\quad$ Always be alert to sights and sounds in the classroom.

- $\quad$ Arrange the seats so that students are always within eyesight.

- $\quad$ Scan the room while working with individuals or small groups of students. When helping an individual student, make sure that you do not have your back to the rest of the class.

- Briefly acknowledge misbehavior at first detection; let the class know that you know. Do not let misbehavior escalate before action is taken.

- $\quad$ Overlapping: The teacher's ability to effectively handle two classroom events at the same time instead of becoming engrossed in one event and letting the other actions occur due to neglect. 
- When instructing one group, the teacher should be able to acknowledge difficulties students outside of the group may be having so that instruction continues to flow smoothly. This includes handling distractions from outside the classroom.

Ripple Effect: Kounin believed how a teacher handles one student's misbehavior influences the other students who are not misbehaving and promotes good behavior.

Desist: When a teacher reprimands one student and other students stop their inappropriate behavior.

Smoothness: The teacher's ability to smoothly transition between learning activities.

Teachers should:

- $\quad$ Preplan the lesson so that extraneous matters are realized and taken care of ahead of time. Supplies for the class should be preorganized before class begins. These materials should be close to location where they will be used.

- $\quad$ Once students are engaged in their work, the instructor should not distract them. Instructors should leave students to their work and assist students with questions or needs.

Momentum: The teacher's ability to have steady movement or pacing throughout a lesson. If a class has momentum, the teacher should:

- $\quad$ Keep the lesson briskly moving.

- $\quad$ Not dwell on a minor or previously understood concept.

- $\quad$ Correct students without nagging and quickly return to the lesson.

- Have students move from one activity to the next without being forced to wait for other students or the next step in lesson transition.

Group Alerting: The teacher's ability to keep all students actively participating and to create suspense or interest. It includes:

- $\quad$ Calling on students at random by asking a question only after scanning the room to make sure students are paying attention.

- $\quad$ Raising group interest by interspersing suspense between questions.

- Having the entire class respond in unison.

- $\quad$ Being mobile and asking students to show what they have done.

- $\quad$ Asking one student to respond and look at others.

\section{CONCLUSION}

It may amaze those in education that in this age of technology and computers, how basic concepts of classroom teaching are similar or even more important than they were 40 years ago when Kounin first defined the elements of withitness. New challenges, related to laptop Internet instruction, require instructors to develop "withitness" skills and situational awareness as they compete with computers for students' attention or participation.

\section{AUTHOR INFORMATION}

Dr. Larry McDaniel Associate Professor Department of Physical Education \& Exercise Science, Dakota State University, USA. Dr. McDaniel was a First Team All-American football player (USA Football), a Hall of Fame Athlete, and Hall of Fame Wrestling Coach. Dr. Larry W. McDaniel teaches the following classes: Kinesiology, Exercise Physiology, Introduction to Research, Nutrition, Stress Management, Fitness for Special Populations, and Risk Management. The last four classes have been developed as Internet courses. He previously taught at Chadron State College, in Chadron NE and Jamestown College in North Dakota. 
Allen Jackson, Assistant Professor, Department of Health, Physical Education \& Recreation at Chadron State College, USA. Allen Jackson is a former student of Dr. McDaniel's. McDaniel was Allen's advisor while he was earning his Masters Degree. He is well known for his presentations \& publications at international conferences focusing on Leadership, Curriculum, and Health. He is a dynamic, animated, and interesting to listen to when presenting at conferences. He is currently in the process of completing his Dissertation.

Dr. Laura Gaudet Department Chair \& Professor Department of Psychology, Counseling, \& Social Work, Chadron State College, USA. Dr. Gaudet is well known for her publications and presentations at international conferences focusing on various topics in the field of psychology. Her preparation for teaching in education includes degrees in Counciling, Special Education, and Pyschology. She is a cancer survior.

Dr. Andrew Shim, Associate Professor Physical Education \& Exercise Science, Dakota State University, Madison, South Dakota USA. Dr. Shim is a well know in the field of research and has several publications in various research journals. Before coming to Dakota State University his was employed at Indiana University in Pennsylvania. He has several leadership roles in various organizations related to Exercise Science. Dr. Shim teaches the following classes; Biomechanics, Test \& Prescription, Motor Learning, Stregnth Training, \& Nutrition classes.

\section{REFERENCES}

1. Johnston, D. (1995). Withitness: Real or fictional? Physical Educator, 95(52), 22.

2. Kounin, J. (1970). Discipline and group management in classrooms. New York: Holt, Rinehart and Winston.

3. McGill, R. A. (2006). Motor learning and control: Concepts and applications. ( $8^{\text {th }}$ ed.). Boston, MA: McGraw-Hill.

4. Melnick, S. A. \& Meister, D.G. (2008). A comparison of beginning and experienced teachers' concerns. Educational Research Quarterly, 31(3), 39.

5. Wolfgang, C. H. (2001). Solving discipline and classroom management problems: Methods and models for today's teachers. New York: John Wiley and Sons.

6. Wuest, D. (1999). Are you with it? Learning environment article. Blacksburg, VA. Retrieved December 10, 2008, from http://www.pecentral.org/climate/april99article.html 
NOTES 